\title{
Treating Employees Equally or Differently? Towards a Theory of Idiosyncratic Human Resources Management
}

\author{
Hui Jing* \\ School of Business, Zhengzhou University, 100 Science Street, Zhengzhou 450001, China \\ E-mail of the corresponding author: jhuixj@163.com \\ Yafei Li \\ School of Business, Zhengzhou University, 100 Science Street, Zhengzhou 450001, China
}

\begin{abstract}
Under the environment of VUCA (Volatility, Uncertainty, Complexity, Ambiguity), organization's development is increasingly relying on human resources with specific skills and abilities. But it is becoming more and more challenging to manage such employees. The traditional standardized human resource management (HRM) mode, which pays attention to the "best fit" or "best practice" has been unable to play its role effectively any more. In the past several years, scholars have proposed the idea of differentiated management (Marescaux \& Sels 2013) used to direct the management of talent resources. However, there still lacks an in-depth investigation of differentiated HRM, especially from the perspective of employees' characteristics. This research aims to develop a theory of idiosyncratic HRM which implements differentiated management to different people (or groups) in recruitment and selection, training and development, performance appraisal, salary and welfare, and employee relationship according to employees' personality and need characteristics. This research not only provides a new perspective for HRM research, but also has practical significance for the reform and innovation of organization's HRM system. Keywords: best fit, best practice; idiosyncratic human resource management
\end{abstract}

DOI: $10.7176 / \mathrm{EJBM} / 13-3-01$

Publication date: January $31^{\text {st }} 2021$

\section{Introduction}

In current times, the loss and management of talent resources is a common and severe problem for many organizations. Why is it so difficult to manage human resources with specific skills and capabilities? This is a "headache" question for many organizations. For a long time, the traditional HRM mode which pays attention to "best fit" or "best practice" regards employee as the passive recipient of employment relationship and advocates that organization should follow "standardized" HRM mode.

However, with the development of society, employment relationship and employee's values are changing, and more and more employees have unique skills or capabilities. In this context, employee no longer focuses only on material income, but also pursue career development, quality of work and life, and the realization of self-worth. Moreover, changes coming from the labour market also place more pressure on organization to recruit, motivate and retain valuable staff. All of these bring more significant challenges to traditional "standardized" HRM mode.

Facing these challenges, scholars are searching for the so-called "best practices" actively, and they believe that there exists a set of universal HRM practices that can help organization achieve high performance (Pfeffer 1994). Even if we accept the "best practices" hypothesis, there is still a great deal of controversies about what are the components of the bundle of "best practices", and more importantly, this mode ignores the heterogeneity characteristic of employee individual. Because of the individual differences, employment relationship based on "exchange" must meet the differentiated characteristics and needs of employees. Only in this way, it becomes possible to realize expected employee behaviour and high performance.

In the same time, strategic HRM researches try to search "best fit" between HRM functions and external environment from organizational macro level, but it still lacks investigation on individual characteristics of employees and its fit with organization from micro personal level. Therefore, it is vital to construct an idiosyncratic HRM mode based on employees' individual characteristics and needs differences.

\section{2. "Best fit" and "Best practice" in HRM}

Since the 1970s, inspired by successful cases of famous companies and the battle for talents, as a discipline, HRM has received unprecedented attention and rapid development. The role of human resources has also been universally recognized, and it is regarded as a kind of essential resource to organization development and a key element to helping organization achieve strategy goal (Wright \& McMahan 1992; Collins \& Clark 2003). Therefore, organization must allocate and use its human resources around strategy and build an efficient HRM system. So there form two main research streams in current HRM field, the "best fit" mode and the "best practice" mode (Stavroua et al. 2010). 


\section{1. "Best fit" mode}

"Best fit" mode derived from strategic HRM researches, and it believes that HRM system may be effective when it matches organization's strategy and the external environment. Therefore, the construction of HRM system should focus on the problem of matching realization, including the matching of HRM activities with organization's strategic goal, and with other functional management activities of the organization, and the matching of HRM activities themselves (Devanna et al. 1981; Doty et al. 1993; Wright \& Snell 1998; Boxall \& Purcell 2000). Just as Schuler \& Jackson (1987) pointed out that HRM activities should be able to strengthen and match behaviours that contribute to the realization of "general strategy (cost leadership, differentiation or focus)" proposed by Porter (1985).

Baird \& Meshoulam (1988) also pointed out that HRM practices must fit organization's development stage (external fit), and themselves each other (internal fit) for ensuring HRM system's effectiveness. External fit refers to the matching between HRM practices and other organizational functional activities and strategic goal, and this matching means that HRM system is firmly rooted in organization's operational system and plays an essential role in strategic goals realization. Wright \& Snell (1998) also pointed out that this kind of fit is the best when HRM practices can jointly promote the realization of organizational goals.

Internal fit refers to the matching among various HRM practices. Wright \& McMahan (1992) pointed that there should create a kind of matching between HRM practices to promote complementarity rather than competition. MacDuffie (1995) and Ichniowski (1997) pointed out that the effectiveness cannot be fully realized unless mutually adapted HRM practices are integrated. Therefore, it is necessary to combine different HRM practices organically to form a bundle and exert synergistic effect.

\section{2. "Best practice" mode}

"Best practice" has received most attention in HRM researches. It considers that there are some best HRM practices, and they have direct impact on performance. For example, some HRM practices, such as performance-related incentive compensation, strict recruitment process, etc., can always bring better performance regardless of industry or organization strategy. The most famous definition of "best practice" comes from Pfeffer's (1994) research. He argued that HRM includes 13 "best practices". Huselid (1995), Delery \& Doty (1996), Ichniowski et al. (1997) further summarized the content of "best practice" and found that most of them are the same as Pfeffer's definition. Later, other researches followed this framework to explore "best practices" and its impact on employee behaviour, attitude and performance.

Huselid (1995) found the adoption of "best practices" could reduce employee turnover, improve productivity and financial performance based on survey data from 968 companies in multiple industries. Berg (1999) found the impact of "best practices" on employee job satisfaction is related to the definition of job role and job responsibility, etc. Applebaum et al. (2000) found that the use of "best practices" is associated with higher stock market value and labour productivity. Combs et al. (2006) found that High performance HRM system, which is composed of employee training, salary level, employee participation, employee selection, internal promotion, human resource planning, flexible working hours, appeal procedure and employee safety, had positive impact on organization performance by a meta-analysis to 92 researches.

In fact, the impact of HRM system on organization performance is to improve employee behaviour and attitude and contribute to the formation of competitive advantage through environment construction, but there are few studies on how "best practices" affect employees' attitude and behaviour at individual level (Guest 2011). Only a few scholars, such as Wu \& Chaturvedi (2009), explored the relationship between "best practices" and employee attitudes (emotional commitment and job satisfaction), and found that the "best practices" has positive impact on employee attitudes. Takeuchi et al. (2009) argued that organization-level employee consideration completely mediates the relationship between the "best practices" and employee job satisfaction and emotional commitment. Wei et al. (2010) conducted a cross-level study on the relationship between "best practice" and organizational citizenship behaviour and found that the "best practice" is positively correlated with employee satisfaction.

\subsection{Summary}

The "best fit" mode emphasizes coordination and consistency among HRM activities in improving organization performance, but it obviously has some problems (Boxall \& Purcell 2000). First, it regards HRM as a rational tool to attain organizational strategic goal but fails to recognize employees' characteristics and its management. Under the background that human resources are becoming critical resources for organization development and strategy objectives realization, effective measures must be taken to meet human resources' characteristics and needs. Only in this way the potential and strategic supporting role of human resources can be brought into full play (Boxall 1998). Second, it lacks adaptability in describing business strategy. Because of the multi-dimensional and changeable nature of organization's strategy, it is extremely difficult and unwise to classify and match HRM practice activities with organization's strategy based on typology (Miller 1992). 
Of course, the "best practice" mode also has some shortcomings. For example, "Contingent performance pay" applicable to U. S. context is not necessarily applicable in the U. K., and at least its effect is not obvious (Wood 1996). Only when the following conditions are met can HRM practice have impact on organization's performance (MacDuffie 1995), employees have the knowledge and skills that managers lack, employees are motivated and willing to use this knowledge and skills, and when employees contribute their efforts, the organization can achieve its strategy.

In brief, the "best bit" and the "best practice" modes treat employees equally and were developed on a common premise: human resources in organization are homogeneous, the organization is the active actor and the employees are the passive recipients in employment relationship. Pankhurst \& Livingstone (2006) argued that employees are heterogeneous, and their knowledge and cognitive ability are also significantly different. Moreover, with the increasing dependence of organization on talents and the enhancement of labour market liquidity, employment relationship is changing from the organization-cantered to the dual mode co-dominated by organization and employees. In this context, how to manage human resources effectively is becoming a fundamental problem faced by many organizations (Thunnissen et al. 2013). As a result, HRM modes that focus on employee individual characteristics and needs are provided, such as differentiated HRM (Marescaux \& Sels 2013), Idiosyncratic Deal (i-deal, Rousseau 2001), etc.

\section{Review of related research}

\subsection{I-deal}

Rousseau (2001) theorized the notion of i-deal and asserted that it represents an alternative advantage to attract talented employees by targeting to individuals' needs, and it viewed i-deal as "an individualized arrangement between valued workers and their employer as the product of negotiation". I-deal can be negotiated during recruitment/selection (i.e., ex-ante i-deal) or ongoing employment relationship (i.e., ex-post i-deal). I-deal also commonly takes the forms of task and development i-deal, providing employees with training, development and career growth opportunities, or flexible work arrangement regarding when and where work is carried out (Rousseau 2005). Anand et al. (2010) argued that i-deal exists broadly in a workplace context.

Hornung, Glaser and Rousseau (2010) explored the outcomes of i-deal negotiations. In a longitudinal study on U.S. hospital employees, they found that successful i-deal negotiations could lead to higher job satisfaction through increased perceptions of job autonomy and outcome fairness. Hornung and colleagues' $(2008 ; 2010)$ demonstrated the benefits of i-deal perceived by employees, whereas other scholars also revealed the benefits of i-deal form organization's perspective (Hornung et al. 2009; Anand et al. 2010).

Scholars also examined the effects of different types of i-deal on employees' attitude and behaviour. I-deal can reduce employees' perceptions of work-family conflict (Hornung et al. 2008), enhance employees' perceptions of work complexity and control (Hornung et al. 2010), job autonomy, outcome fairness, job satisfaction (Hornung et al. 2010; Rosen et al. 2011). Benefits to organization include the enhancements in favourable employee attitudes, such as affective organizational commitment (Hornung et al. 2008; Ng \& Feldman 2010; Rosen et al. 2011), motivation (Hornung et al. 2009), perceived organizational support (Rousseau \& Kim 2006), and exchange relationship quality with organization (Rousseau et al. 2009). Organization also benefits from i-deal through positive employee behaviours, such as working unpaid overtime hours (Hornung et al. 2008), and engaging in citizenship behaviours towards co-workers, managers and organization (Anand et al. 2010).

\subsection{Flexible work arrangement}

In the 1970s, flexible work arrangement (FWA) first appeared in U. S. and it was used to attract and retain highskilled employees. But in the late 1990s, with the shortage of labour, it was extended to general employees gradually. Workplace Flexibility 2010 defines FWA as any one of a spectrum of work structures that alters the time and/or place that work gets done regularly, and it includes: flexibility in the scheduling of hours worked, such as alternative work schedules (e.g., flex time and compressed workweeks), flexibility in the amount of hours worked, such as part time work and job shares, flexibility in the place of work, such as working at home. O'Brien et al. (2007) argued that FWA usually includes flexible working hours, work sharing, part-time work, compressed work week, work breakdown, remote work, work from home, etc., and these arrangements are helpful to employees' work-life balance.

Why does FWA widely accepted by organizations and employees? Lewis \& Campbell (1998) argued that there are five main reasons, meeting the needs of workers, catering to the goal of family friendliness, the influence of social politics, the development of equality idea, and organization's business practice (including the shortage of technical talents, employee retention, avoidance of workplace pressure, reduction of absenteeism, etc.). Sheridan \& Conway (2001) argued that business practice is the main reason for a flexible working system. FWA means that under certain conditions, employees can flexibly and independently choose the specific time, place or content of work, which is obviously different from the traditional work arrangement. The most important reason why it can be accepted by organization and employee is that it can bring win-win results for organization and 
employees. In other words, FWA can create more learning and self-improvement opportunities for employees, so that employees can enjoy life and pursue spiritual satisfaction while working hard.

\subsection{Flexible job design}

Job design and analysis is the division of work tasks assigned to individual in an organization that specifies what the worker does, how, and why. Job design is an important construct of an HRM system. Its role is to conduct detailed analysis to job or position to enable the (a) recruitment or (b) assessment of performance becoming feasible. In organization, to identify the best person for the job or position, it is crucial to fully understand the nature of the job or position fully, and job design provides a way to develop this understanding by examining the tasks performed in a job or position, the competencies required to execute tasks, and the connection between the tasks and competencies. Effective job design contributes to the achievement of organizational objectives, motivation, and employee satisfaction.

Traditional job design is generally based on job analysis and requirements, lacks consideration to human factors. Flexible job design refers to the process of defining tasks, responsibilities, powers of each position and its relationship with other functions based on job analysis information in which the needs of the organization and employees must be considered. Specifically, flexible job design connects job requirements with personnel requirements to promote the realization and improvement of organization goals and satisfaction of employees. Flexible job design can increase the richness of work, stimulate the enthusiasm of employees, reduce the work fatigue and boredom of employees. From this perspective, flexible job design is an important HRM function that can adapt to the changes in the labour market and employees' characteristics.

\section{A Theoretical framework of Idiosyncratic HRM}

\subsection{Definition of idiosyncratic HRM}

Traditional HRM mode regards employees as machines and tools simply, and usually pays more attention to their common characteristics, but ignores other personality differences and diversified individual needs of employees. This kind of management principle seems simple and straightforward, but extensive. Employees in similar position get same bonus, same salary and welfare, it could save management cost and ensuring organization efficiency and fairness, but it is hard to retain excellent or valued talents. The fundamental reason is that it couldn't meet the talent's diversified individual needs. A new mode must be developing to replace it.

Miner (1987) argued that personalized work style could be adopted as a special work arrangement to employees to cope with challenges brought to organization by resources uncertainty and variability and organization size's continuous increase. For example, for an employee with outstanding oral expression ability, a customer telephone service post can be arranged for him to give full play to his special ability. Lawler III \& Finegold (2000) also argued that there is no any standardized method to manage employees effectively due to the differences in abilities and job expectations, so HRM must be more and more personalized. Vera van Zijderveld (2011) pointed out that organizations are also willing to adopt differentiated talent segmentation management strategies and adopt different management mode for different employees in attracting, developing and retaining valued human resources. Based on AMO (Ability, Motivation, Opportunity) theory, Jiang et al. (2012) divided HRM system into three types (skill-enhancing, motivation-enhancing and opportunity-enhancing) to meet the needs of differentiated management of employees.

With the development of HRM theory, HRM mode, which absorbs the thoughts of "best practice" and "best fit" and focuses on personality and needs characteristics of employees, will be paid more and more attention. Although personalized management will inevitably lead to some problems, such as undermining employees' relationship with his co-workers or the organization (Rousseau 2005; Greenberg et al. 2004; Lee \& Bachrach 2015), it is more suitable for attracting, retaining and encouraging valued talents. Beker et al. (2009) also argued that differentiated management is an important way to help organizations achieve strategic objectives. Marescuux (2013) put forward the concept of differentiated HRM and pointed it could be embodied in various forms, such as bonus, welfare, training, evaluation and guidance of employee development, self-management, the flexibility of working time and place, etc.

At the same time, with the improvement of living standard, people aim to pursue higher level quality of work and life. Employees' work motivation is no longer only for survival, economic reward and safety, also for the realization of respect, sense of honour and self-worth. Employees' work needs are becoming diversified and differentiated, so HRM increasingly should consider need characteristics of employees. In this context, we defined idiosyncratic HRM as a kind of management mode that focuses on personality differences and need characteristics of human resource individual or group and aims to achieve organization goals under the guidance of strategy by providing personalized solutions in recruitment and selection, training and development, performance appraisal, salary and welfare, and employment relationships. In brief, idiosyncratic HRM aims to implement differentiated management to different people (or groups) in recruitment and selection, training and development, performance appraisal, salary and welfare, and employee relationship in accordance with their personality and need 
characteristics.

\subsection{Characteristics of idiosyncratic HRM}

Based on the definition above mentioned, the characteristics of idiosyncratic HRM cam be summarized as follows. First, idiosyncratic HRM is an employee-cantered management mode. Idiosyncratic HRM integrates and reflects the individual differences and needs of employees into various HRM activities, and even implements tailor-made management to employees. In other words, idiosyncratic HRM tries to promote employees' job performance by satisfying their diversified individual needs, respecting their unique interest demands and stimulating their working enthusiasm.

Second, the essence of idiosyncratic HRM is differentiated management to employees. In idiosyncratic HRM, human resources individual or group should be treated differently to meet their differentiated needs. For example, a certain tool may have significant incentive effect on one employee, but due to the differences among employees, the incentive effect may be not significant on other employees. Therefore, idiosyncratic HRM treats employees different from person to person.

Third, idiosyncratic HRM pursues a win-win situation between organization and employees. On one hand, idiosyncratic HRM commits to meet individual needs of employees, and maximize their work potential. On the other hand, employees will also give back to the organization with high performance and high loyalty, and try to create value for organization, and strive for the realization of organization's strategy goals.

\subsection{Constructs of idiosyncratic HRM}

Following the content framework of traditional HRM, the constructs of idiosyncratic HRM can be summarized as follows: idiosyncratic recruitment and selection, idiosyncratic training and development, idiosyncratic performance appraisal, idiosyncratic salary and welfare, idiosyncratic contract/deal, etc. (Figure 1.).

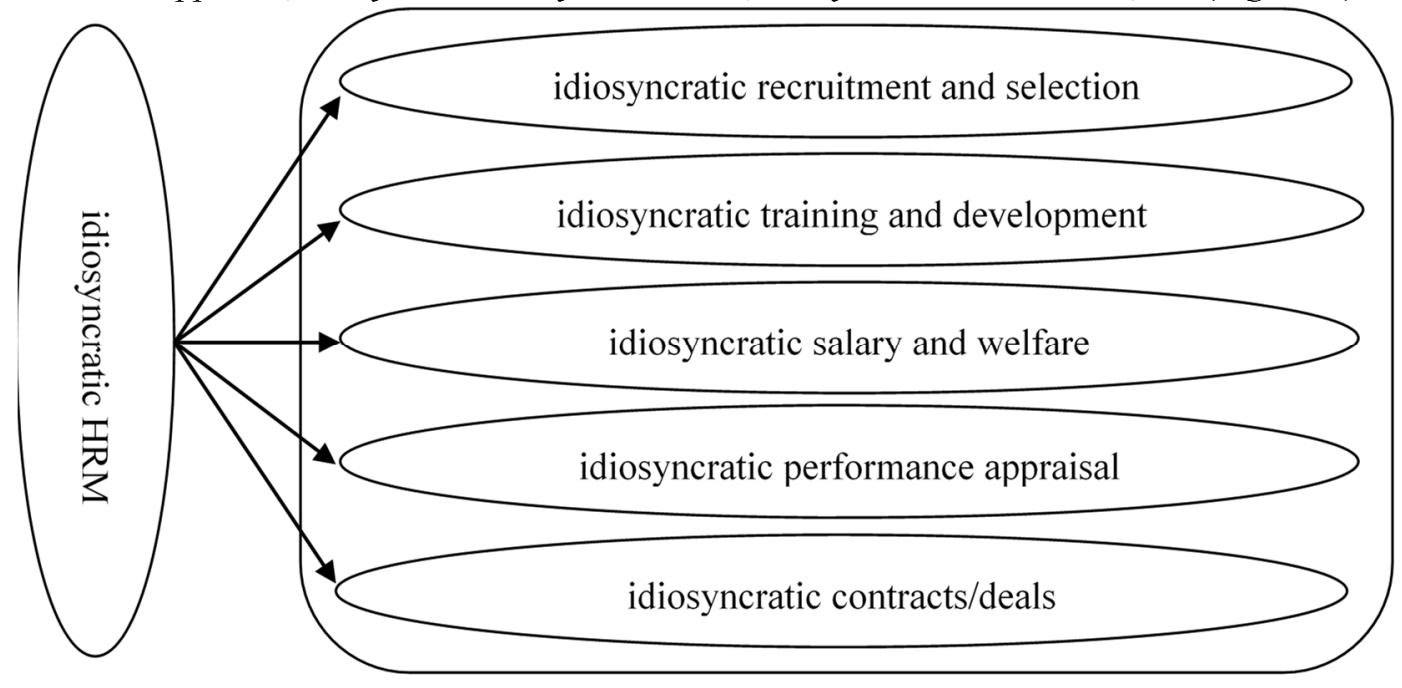

Figure 1. Constructs of idiosyncratic HRM

4.3.1 Idiosyncratic recruitment and selection

In an increasingly competitive environment, organizations must formulate effective methods to recruit and select human resources suitable for the organization's development needs to establish competitive market advantages. In traditional recruitment and selection, an organization often adopts a unified method from their perspective to assess whether candidates meet the requirements of the position. Of course, there may be some differences in recruitment and selection methods due to the differences in job responsibilities, but most of them are standardized mode.

In practice, there are apparent differences in the responsibilities among different positions within the organization, and the employment standards of position are also others, which leads to different selection methods. Therefore, it is necessary to reflect the personalized needs of positions in employee recruitment and selection. Besides, an organization should also provide candidates with detailed information about the job and position, so that they can clearly understand the specific requirements and form an accurate expectation on whether they accept the job or not.

Idiosyncratic recruitment and selection are embodied in choosing different recruitment channels according to different sources of employees, using different selection and testing methods according to different job requirements, to achieve the purpose of "making suitable people doing the right job" on the base of the job analysis. For example, due to differences in job responsibilities and requirements, the recruitment channels and selection methods between senior managers and general managers may be very different. In brief, Idiosyncratic recruitment and selection committed to achieving the goal of person-job fit by considering individual differences of applicants 
and the different position standards by using different methods.

4.3.2 Idiosyncratic training and development

In an organization, employees in different positions have different educational backgrounds, experiences, knowledge and skills, and different career development goals, so how to formulate training and development management system in line with employees' characteristics and needs should be considered. The traditional training and development mode of HRM usually focuses on unified training content, unified training mode and unified training course, and it is challenging to solve skill improvement problem required by employees, and it is also difficult to promote knowledge accumulation required by employees' career development effectively. Idiosyncratic training and development management system could be designed on the principle of meeting the needs of positions and employees.

In practice, idiosyncratic training and development is mainly reflected in the design and formulation of targeted training plans according to the needs of positions and employees, such as the differentiation and diversification of training contents, training courses, and training methods. It advocates to promote categorized teaching in accordance with employees' aptitude, to adjust course arrangements, to update training content, to improve training methods in a timely manner according to changes in job conditions and employee needs to maximize training effects. It also designs training and development system considering the needs of employees' career development, so that employees and organization can grow and develop together.

4.3.3 Idiosyncratic salary and welfare

Idiosyncratic salary and welfare refer to establishing a differentiated salary system considering the different value of the position, the diversified needs and other job performance of individual employees in an organization. Its most significant characteristics are diversity, customization and dynamism of salary and welfare. Its essence is employee-cantered, and each employee can determine their own salary portfolio and the proportion of salary elements according to their career development, work and life conditions under this system.

In idiosyncratic salary and welfare system, a position salary system that reflects the differences and the relative value of positions is established, and a flexible rewards and menu-type welfare system is also set up that reflects the differences of individual performance. In addition, organizations can also design flexible package of welfare for employees on the base of considering differentiated needs of different employees. For example, employees can choose health check-ups, special insurance, shopping cards or traveling abroad according to their needs. By this, employees can have higher satisfaction, and in turn their stronger work enthusiasm could be inspired.

4.3.4 Idiosyncratic performance appraisal

Idiosyncratic performance appraisal mainly refers to designing and adopting different performance evaluation indicators for different positions, and different evaluation indicators also should be evaluated by different evaluation subjects. It means to evaluate what the position requires employee to do, and to let the subjects who know clearly what the employees do to evaluate the employees. It also should carry out differentiated performance communication and feedback according to the characteristics and results of different employees and formulate targeted performance improvement plan to ensuring the effectiveness of the performance appraisal.

In practice, idiosyncratic performance appraisal is first reflected in the diversity of indicators, such as ability indicators, behaviour indicators and performance indicators. Second, performance appraisal not only pays attention to the particularity of employees' job differences, but also ensures the fairness of performance appraisal system in designing evaluation indicators. Third, the subjects of performance evaluation may be different. Participants may include employees themselves, their supervisors, and even relevant parties connected with their job. Fourth, due to the differences of job responsibilities, performance results, and personal abilities, different performance communication and improvement plans should also be adopted.

4.3.5 Idiosyncratic contract/deal

Idiosyncratic contract/deal refer to personalized/individualized employment relationship arrangements. Rousseau (2005) argued that the idiosyncratic deal includes idiosyncratic career development opportunities, flexible working hours, flexible working places, etc. Of course, idiosyncratic contract/deal is not a disorderly employment arrangement, nor is it free and unorganized labour relationship. It is a kind of work arrangement according to special circumstances and needs of employees in line with the interests of both organizations and employees.

In practice, idiosyncratic contract/deal could be flexible arrangement in working time and place, shortening work week, working remotely or at home. It also can be embodied in personalized work design, flexible employment mode in work content or type, work sharing, employee participation or employee development plan. In brief, idiosyncratic contract/deal tries to build employment relations on respecting employees' special needs, and to mobilize employees' work enthusiasm to the greatest extent.

\section{Conclusions and future research directions}

Based on the traditional HRM theory and the idiosyncratic deal theory proposed and developed by Rousseau (2005), this paper forms a theoretical framework of idiosyncratic HRM. It will mainly focus on three critical issues 
in the future researches: (1) What is idiosyncratic HRM? (What the contents of idiosyncratic HRM include? What the similarities and differences between it and the traditional standardized HRM mode are? How to measure it? which constructs it include? (2) What effect does idiosyncratic HRM have on employee job satisfaction, organizational citizenship behaviour, and organizational commitment, etc. (What the influence mechanism of idiosyncratic HRM practice on employee behaviour and attitude is?) (3) How does idiosyncratic HRM affect employee job performance and organization performance? (Whether and how the impact of idiosyncratic HRM on employee behaviours and attitudes contributes to job performance or organization performance improvement?).

\section{References}

Anand, S., Vidyarthi, P., Liden, R. C. \& Rousseau, D. M. (2010). Good Citizens in Poor-quality Relationships: Idiosyncratic Deals as a Substitute for Relationship Quality. Academy of Management Journal, 53(5), 970 988.

Applebaum, E., Bailey, T., Berg, P. \& Kalleberg, A. L. (2000). Manufacturing Advantage: Why High-performance Work Systems Pay off. Ithaca, Cornell University Press.

Baird, L., \& Meshoulam, I. (1988). Managing two Fits of Strategic Human Resource Management. Academy of Management Review, 13(1),116 128.

Beker, B. E., Huselid, M. A., \& Beatty, R. W. (2009). The Differentiated Workforce. Boston, Harvard Business Press.

Berg, P. (1999). The Effects of High-performance Work Practices on Job Satisfaction in the United States Steel Industry. Relations Industrials, 54(1), 111 134.

Boxall, P. (1998). Achieving Competitive Advantage through Human Resource Strategy: Towards a Theory of Industry Dynamics. Human Resource Management Review, 8(3), 265 288.

Boxall, P., \& Purcell, J. (2000). Strategic Human Resource Management: Where have We Come from and Where should We be Going? International Journal of Management Reviews, 2(2), 183 203.

Collins, C. J., \& Clark, K. D. (2003). Strategic Human Resource Practices, Top Management Team Social Networks, and Firm Performance: The Role of Human Resource Practices in Creating Organizational Competitive Advantage. Academy of Management Journal, 46(6), 740 751.

Combs, J. A., Liu, Y. M., Hall, A. N. \& Ketchen, D. A. (2006). How much do High-performance Work Practices Matter? A Meta-analysis of Their Effects on Organizational Performance. Personnel Psychology, 59(3), $501 \sim 528$.

Delery, J, E, \& Doty, D. H. (1996). Modes of Theorizing in Strategic Human Resource Management: Tests of Universalistic, Contingency, and Configurational Performance Predictions. Academy of Management Journal, 39(4), 802 835.

Devanna, M. A., Fombrum, C., \& Tichy, N. (1981). Human Resource Management: a Strategic Perspective. Organizational Dynamics, 9(3), 51 67.

Doty, D. H., Glick, W. H., \& Huber, G. P. (1993). Fit, Equifinality, and Organizational Effectiveness: A Test of two Configurational Theories. Academy of Management Journal, 36(6), 1196 1250.

Greenberg, J., Roberge, M. E., Ho V. T., Rousseau, D. (2004). Fairness in Idiosyncratic Work Arrangements: Justice as an I-deal. Research in Personnel and Human Resources Management, 23, 1 34.

Guest, D. E. (2011). Human Resource Management and Performance: Still Searching for Some Answers. Human Resource Management Journal, 21(1), 3 13.

Hornung, S., Rousseau, D. M., \& Glaser, J. (2008). Creating Flexible Work Arrangements through Idiosyncratic Deals. Journal of Applied Psychology, 93(3), 655-664.

Hornung, S., Rousseau, D. M., \& Glaser, J. (2009). Why Supervisors Make Idiosyncratic Deals: Antecedents and Outcomes of I-deals from a Managerial Perspective. Journal of Managerial Psychology, 24(8), 738 764.

Hornung, S., Rousseau, D. M., Glaser, J., Angerer, P., \& Weigl, M. (2010). Beyond Top-down and Bottom-up Work Redesign: Customizing Job Content through Idiosyncratic Deals. Journal of Organizational Behavior, 31(2-3), 187 215.

Huselid, M. A. (1995). The Impact of Human Resource Management Practices on Turnover, Productivity, and Corporate Financial Performance. Academy of Management Journal, 38(3), 635 672.

Ichniowski, C., Shaw, K. \& Prennush, G. (1997). The Effects of Human Resource Management Practices on Productivity: a Study of Steel Finishing Lines. American Economic Review, 87(3), 291 313.

Jiang, K. F., Lepak, D. P., Hu, J., \& Bear, J. D. (2012). How dose Human Resource Management Influence Organizational Outcomes? A Meta-analytic Investigation of Mediating Mechanisms. Academy of Management Journal, 55(6), 1264 1294.

Lawler III, E. \& Finegold, D. (2000). Individualising the Organization: Past, Present, and Future. Organizational Dynamics, 29(1), 1 15.

Lee, J. Y., Bachrach, D. G. (2015). Internal Labor Markets, Firm-specific Human Capital, and Heterogeneity Antecedents of Employee Idiosyncratic Deal Requests. Organization Science, 26(3), 794 810. 
Lewis, J., Campbell, M. (2008). What's in a Name? 'Work and Family' or 'Work and Life' Balance Policies in the U.K. since 1997 and the Implications for the Pursuit of Gender Equality. Social Policy \& Administration, 42(5), 524 541.

MacDuffie, J. P. (1995). Human Resource Bundles and Manufacturing Performance: Organizational Logic and Flexible Production Systems in the World Auto Industry. Industrial and Labor Relations Review, 48(2), 197 221.

Marescaux, E., Winne, S. D., \& Sels, L. (2013). H.R. Practices and Affective Organizational Commitment: (When) Does H.R. Differentiation Pay off? Human Resource Management Journal, 23(4), 329 345.

Miller, D. (1992). Generic Strategies: Classification, Combination and Context. Advances in Strategic Managemen, 8, 391 408.

Miner, A. S. (1987). Idiosyncratic Jobs in Formalized Organization. Administrative Science Quarterly, 32(3), $327 \sim 351$.

Ng, T. W. H., \& Feldman, D. C. (2010). Idiosyncratic Deals and Organizational Commitment. Journal of Vocational Behavior, 76(3), 419 427.

O'Brien, M., Brandth, B., Kvande, E. (2007). Fathers, Work and Family Life”, Community Work \& Family, 10(4), 375 386.

Pankhurst, K. V., Livingstone, D. W. (2006). The Labor Process: Individual Learning, Work and Productivity. Studies in Continuing Education, 28(1),1 16.

Pfeffer, J. (1994). Competitive Advantage through People: Unleashing the Power of the Workforce. Boston: Harvard Business School Press.

Porter, M. E. (1985). The Competitive Advantage: Creating and Sustaining Superior Performance. New York: Free Press.

Rosen, C. C., Slater, D. J., Chang, C. H., \& Johnson, R. E. (2011). Let's Make a Deal: Development and Validation of the Ex Post I-Deals Scale. Journal of Management, 39(3), 709 742.

Rousseau, D. M. (2001). The Idiosyncratic Deal: Flexibility versus Fairness? Organizational Dynamics, 29(4), 260 273.

Rousseau, D. M. (2005). I-deals: Idiosyncratic Deals Workers Bargain for Themselves. New York: M. E. Sharpe.

Rousseau, D. M., Ho, V. T., \& Greenberg, J. (2006). I-Deals: Idiosyncratic Terms in Employment Relationships. Academy of Management Review, 31(4), 977 994.

Rousseau, D. M., Hornung, S., \& Kim, T. G. (2009). Idiosyncratic Deals: Testing Propositions on Timing, Content, and the Employment Relationship. Journal of Vocational Behavior, 74(3), 338 348.

Schuler, R. S., \& Jackson, S. E. (1987). Linking Competitive Strategies with Human Resource Management Practices. Academy of Management Executive, 1 (3), 207 219.

Sheridan, A., Conway, L. (2001). Workplace Flexibility: Reconciling the Needs of Employers and Employees. Women in Management Review, 16(1): 5 11.

Stavroua, E. T., Brewsterb, C. \& Charalambous, C. (2010). Human Resource Management and Firm Performance in Europe Through the Lens of Business Systems: Best Fit, Best Practice or Both? The International Journal of Human Resource Management, 21(7), 933 962.

Takeuchi, R., Chen, G. \& Lepak, D. P. (2009). Through the Looking Glass of a Social System: Cross-level Effects of High-performance Work Systems on Employees' Attitudes. Personnel Psychology, 62(1), 1 29.

Thunnissen, M., Boselie, P. \& Fruytier, B. (2013). A Review of Talent Management: Infancy or Adolescence? The International Journal of Human Resource Management, 24(9), 1744 1761.

Vera van Zijderveld. (2011). Talent, I-deals, Talent Segmentation Strategy and Perceived Fairness: The Effects of Differential Treatment. Master Thesis of Human Resource Studies, Tilburg University.

Wei, Y. C., Han, T. S. \& Hsu, I. C. (2010). High-performance H.R. Practices and OCB: A Cross-level Investigation of a Causal Path. The International Journal of Human Resource Management, 21(10), 1631 1648.

Wood, S. (1996). High Commitment Management and Payment Systems. Journal of Management Studies, 33(1), 53 77.

Workplace Flexibility 2010. (2006). Flexible Work Arrangements: a Definition and Examples. Georgetown University Law Centre.

Wright, P. M., \& Snell, S. A. (1998). Toward a Unifying Theory in Exploring Fit and Flexibility in Strategic Human Resource Management. Academy of Management Review, 23(4), 756 772.

Wright, P. M., McMahan, G. C. (1992). Theoretical Perspectives for Strategic Human Resource Management. Journal of Management, (18), 295 320.

Wu, P. C. \& Chaturvedi, S. (2009). The Role of Procedural Justice and Power Distance in the Relationship between High-performance Work Systems and Employee Attitudes: a Multi-level Perspective. Journal of Management, 35(5), 1228 1247. 